\title{
On the Green Development Road of Ecological Agriculture Weiwei Liu ${ }^{1}$ and Leifeng Wang ${ }^{2}$ Jingdezhen Ceramic University, Jingdezhen, Jiangxi 333403
}

\begin{abstract}
Ecological agriculture is generated from the perspective of green development theory and in the circumstance that China is facing the destruction of the environment. It requires coordinated development with the environment to meet the requirements of green development theory, and it also promotes the perfection of green development theory and sustainable development of China's economy, which is beneficial for China to construct a society with ecological civilization.
\end{abstract}

Keywords: Green development theory; Perspective; Ecological agriculture; Origin; Development

\section{论析生态农业的绿色发展之路}

\author{
刘伟伟 ${ }^{1}$ 王䂞峰 $^{2}$ \\ ( 景德镇陶瓷大学; 江西 景德镇 333403 )
}

摘要: 生态农业是在绿色发展理论视野下, 中国面临环境的破坏的情况下产生的。它要求实现其之间与环境的协调发展, 确保符合绿色发展理论的要求, 同时又促进了绿色发展理论的完善与运用以及中国经济的可持续发展, 有利于中国建成生态 文明社会。

关键词: 绿色发展理论; 视野; 生态农业; 由来; 发展

中图分类号: A81 文摘标识码: A

\section{引言}

生态农业是在绿色发展理论基础上形成与发展起来的，强调农、林、牧与渔等和谐发展，要求实现其 之间与环境的协调发展, 确保符合生态理论的要求, 促进中国经济的可持续发展, 进而建成生态文明社会。

\section{1. 生态农业产生的理论来源}

\section{1 生态农业受马克思与恩格斯生态思想的影响}

第一，马克思的物质变换与物质循环断裂思想。在《资本论》第一卷中，马克思认为，资本主义生产 使它在各大中心的城市人口越来越占有优势。它一方面聚集着社会历史的动力, 另一方面又破坏着人和土 地之间的物质变换，使人以衣食形式消费掉的土地的组成部分不能回到土地，从而破坏土地的持久肥力的 永恒的自然条件。在马克思看来, “资本主义农业的任何进步, 都不仅是掠夺劳动者的技巧的进步, 而且 是掠夺土地的技巧的进步, 在一定时期内提高土地肥力的任何进步, 同时也是破坏土地肥力持久源泉的进 步。” ${ }^{[1]}$

第二，恩格斯的生态思想。恩格斯曾指出：“我们不要过分陶醉于人类对自然界的胜利。对于每一次 这样的胜利, 自然界都对我们进行了报复。每一次胜利, 在第一步都确实取得了我们预期的结果, 但是在 第二步和第三步却有了完全不同的、出乎预料的影响，它常常把第一个结果重新抵消了。” $\left.{ }^{2}\right]$

\section{2 生态农业受国外生态思想的影响}

在生态环境日益遭到破坏的情况下, 以保护环境为宗旨的绿党与团体的成立等等都催发了生态思想的 产生, 尤其是生态社会主义思想的诞生。如, 蕾切尔・卡逊（Rache1 Carson）的生态思想, 他在《寂静 
的春天》一书中阐述了农药对环境的污染, 用生态学的原理分析了这些化学杀虫剂对人类赖以生存的生态 系统带来的危害, 指出人类用自己制造的毒药来提高农业产量, 无异于饮䴓止渴, 人类应该另谋出路。《寂 静的春天》所列举的人类滥用除草剂和农药给动植物和土地带来的破坏性结果, 震撼了美国人乃至世界, 使一些人开始意识到, 技术的发明和使用不能不考虑生态利益, 短期的获利可能带来持久的损害。

\section{3 生态农业受我国传统农业中朴素的生态思想的影晌}

生态农业受我国传统农业在农业发展中形成的朴素生态思想和技术的影响。如，“千百年来我国农民 在生产实践中始终强调土地的用养结合, 使 ‘力常新壮”、

循环利用、低能消耗; 农书《农桑辑要》、《耕织图》等都强调种植业与各业相结合的思想; 中国古代 用 ‘阴阳五行”、“天人合一”学说解释和处理自然界的奥秘以及人与自然之间的关系。” ${ }^{[3]}$

\section{2. 生态农业概念的提出与科学内涵}

\section{1 生态农业概念的提出}

生态农业（eco-agriculture）一词是由美国土壤学家W ・Albreohe于1970年提出来的，而我国提出生 态农业这一术语, 是建立在国外生态农业这一概念的基础上, 1980年, 王益谦在全国农业生态经济学术讨 论会上提出 “生态农业”。随后生态农业得到学术界与政府的重视。如, “1981年，提出生态农业是能够促 进生态和农业生产良性循环，保护资源环境和符合区域优势原则的农业技术体系。” ${ }^{[4]} 1982$ 年，叶谦吉结合 我国的农业的状况，并借鉴生态思想，提出了个人关于 “生态农业” 概念的理解，即 “生态农业就是从系 统思想出发, 按照生态学原理, 经济学原理和生态经济学原理, 运用现代科学技术成果和现代管理手段以及 传统农业的有效经验建立起来, 以期获得较高的经济效益的现代的农业发展模式。” ${ }^{[5]}$

\section{2 生态农业的科学内涵}

1985年后, 我国政府认识到生态农业的重要性, 要求各级政府重视生态农业的建设, 我国陆续出现了 生态农业示范村。关于生态农业的科学内涵, 学者进行了探讨。如, 生态学家马世骏提出生态工程建设原 理: 整体、协调、整体与再生, 并与李松华一同出版了第一部介绍生态农业的著作《中国的农业生态工程》; “2003年李文华通过设计生态模型，协调经济发展和环境之间的关系、资源利用与保护之间的关系，形成 了经济与生态的良性循环, 实现了农业的可持续发展” ; ${ }^{[6]}$ “2004年张薰华认为未来农业应向着生态农业 的方向发展, 农业生产要符合自然规律, 还应注重城乡统筹, 不能将城市的污染带去农村, 二者要相互促 进, 实现城乡一体化”; ${ }^{[7]}$ “2009年徐更生认为生态农业的基本特征是环境与生物之间的能量转化和物质循 环, 他把农业生产活动视为一种生态系统。” ${ }^{[8]}$ ……总之, 我国对生态农业的内涵有不同的看法, 归纳起来 来看是由浅入深, 由简单到综合。如下面几种反映: “生态农业=生态+农业”、“生态农业=生态+农业+经济”, “生态农业=生态+农业+经济+工程” ……实际上, 这是在结合我国国情的发展, 遵循客观规律的条件下, 逐步对中国生态农业的概念进行完善和丰富的结果。通过上述分析, 得知中国的生态农业的科学内涵应是: 在科学发展观指导下, 结合马克思生态思想、国外生态农业思想和我国传统农业中的精华, 实现农业的可 持续发展，促进生态经济与自然环境的协调，最终实现人的全面发展和社会的生态文明。

\section{3. 当前生态农业的绿色发展路经探析}

\section{1 当前生态农业的发展状况}

目前我国生态农业建设全面展开，从生态农业中，土壤得到改良，有利于作物的生长; 粮食增产，增 
加了农民收入, 改善了农村的生活环境; 绿色食品与生态环境, 有益农民的身心健康等, 当前中国生态农 业建设走上制度化与规范化的道路。但由于中国是世界生态脆弱地区分布面积最大, 生态脆弱性表现最明 显的国家之一。近几十年来, 随着人口的增长和粗放式经济的快速发展, 生态脆弱区固有的人地矛盾进一 步加剧, 严重影响了中国生态农业发展。具体表现在如下几个方面:

第一, 农业劳动者生态理论知识缺失, 生态意识淡薄。由于农村地处相对偏远, 农民较少接受系统的 生态教育, 同时还受到传统农业思想的影响, 使农民仍固守传统的思想观念, 如 “产品高价、资源低价与 环境无价”。在科技思想方面，生态农业中的科技含量高思想往往被过度追求经济利益的传统技术思想 “短、 平与快” 所取代。

第二, 生态农业建设体制不完善。生态农业建设体制的不健全, 间接影响生态农业的发展。当前生态 农业建设的体制还不能完全满足生态农业更好更快的发展需求。如体制分散成为生态农业发展中的障碍, 连锁体系不健全影响生态农产品的 “产、供与销”, 政策配套不及时, 配套服务体制不完善。

第三，政府投入与宣传力度不到位。在生态农业的资金投入方面，政府投入不足，影响生态农业的顺 利进行。如农民在 “推行农业标准化” 方面, 农民没有充足的资金来承担标准化各环节的费用。在对生态 农业的宣传上, 往往针对村干部与个别素质较高的农民, 没有深入到每个村民, 普及生态农业的大众化受到 影响。

第四, 农村土地分散管理, 农村企业规模小。随着城市化进程的发展, 农业资源特别是土地逐渐减少, 农民分散经营土地, 导致组织化程度低, 难以按生态农业发展的要求来组织生产, 因而, 难以形成区域优势。 农办企业总体规模偏小, 缺乏自主创新, 受市场影响因素大, 加之与农民关系相对松散, 总之, 农办企业 没有形成规模优势与品牌优势, 与我国建设生态农业的新形势还有相当差距。

\section{2 走生态农业绿色发展之路径}

党的十八大以来, 中央提出与建设生态农业相关的一系列措施: 建设中国特色社会主义, 全面建成小 康社会, 加快转变经济发展方式, 加强社会建设与大力推进生态文明建设, 为我国生态农业的发展指明了 方向。因此, 我们应按照天人合一, 物我交融的要求, 重视生态环境的和谐。此外结合当前中国面临资源约 束趋紧、环境污染严重与生态系统退化的严峻形势, 因而, 生态农业的发展呈现以下趋势:

1. 在生态农业发展的理论上, 生态农业的发展符合科学发展观的要求, 农民树立起尊重自然、顺应自 然与保护自然的生态文明理念, 生态农业的发展会融入经济建设和社会建设等各方面与全过程, 推动美丽 中国建设与生态文明建设, 实现中国特色社会主义的永续发展。同时, 生态农业的发展在生态经济理论、 可持续发展理论与循环经济理论下, 生态农业发展的理论得以创新。

2. 在生态农业发展的制度上, 十八大提出: “加快建立生态文明制度, 健全国土空间开发、资源节约、 生态环境保护的体制机制, 推动形成人与自然和谐发展现代化建设新格局。”为此, 生态农业在农业基础 设施建设、对农民的培训和农业科技的投入、生态农业服务网络建设方面得到加强, 并逐步在完善农村杜 会保障制度下，生态农业发展的制度得到创新。

3. 在生态农业发展的道路上, 十八大指出: “坚持走中国特色新型工业化、信息化、城镇化、农业现 代化道路, 推动信息化和工业化深度融合、工业化和城镇化良性互动、城镇化和农业现代化相互协调, 促 进工业化、信息化、城镇化、农业现代化同步发展。”为此, 生态农业会在景观道路、循环道路与食物链 
道路下，生态农业发展的道路得到创新。

4. 在生态农业发展的政策上，“生态农业在国家宏观调控下，发挥市场在资源配置中的基础性作用， 促进包括土地在内的资源要素的有序流动, 提高农业的集约化、标准化、规模化的 '三化” 水平和农业的 劳动生产率。” 同时, 生态农业的发展注重节约资源与环境保护的政策，在坚持节约优先、保护优先与自 然恢复为主的方针下，形成绿色发展、循环发展与低碳发展，进而使政策进一步落实，为人民创造更好的 生产生活环境。另外, 还应深化农业区域分工，构筑区域优势互补、主体功能明确、人与地和谐的现代农 业区域格局，不断增强城乡区域发展的协调性。

\section{结语}

通过上述分析, 生态农业自从出现以来, 就表现出强大的生命力, 可以说, “21世纪必将是生态的世 纪、生态文明的新纪元; 生态农业也必将是 21 世纪的阳光产业。” 尤其在中国, 生态农业被赋予新的内容: 生态农业与建成小康社会的目标、建设社会主义新农村的任务相结合等。生态农业的发展必将促进生态农 业理论、制度与道路的创新，同时，生态农业发展的政策得到贯彻，这些会谱写农业历史的新篇章。

\section{致谢}

基金项目: 景德镇陶瓷大学社会科学研究项目 “高兹的劳动观及其当代启示” 的阶段性成果。

\section{Acknowledgement}

Fund Project: Periodical results of Jingdezhen Ceramic University Social Science Research Project "Gao Zizhi 's View of Labor and Its Contemporary Enlightenment".

\section{参考文献}

[1]马克思恩格斯文集（第五卷)，北京:人民出版社，2009:579

[2]恩格斯. 自然辩证法. 北京: 人民出版社, 1984:304-305

[3]王慕镇. 生态文明视野下我国生态农业发展研究. 南昌大学. 2008:29

[4]郡勇. 莱芜北部山区生态农业综合开发与模式研究. 中国海洋大学, 2010: 30-31

[5]叶谦吉. 生态农业. 四川: 重庆出版社, 1988:49

[6]李文华.生态农业一中国可持续农业的理论与实践.化学工业出版社, 2003:20-21

[7]张薰华.循环经济: 实现可持续发展的理想经济模式. 中国科学院院刊. 2004 (6) : 409

[8]李静静. 四川省生态农业建设的绩效评价研究. 四川农业大学, 2011:45-46

\section{作者简介：}

刘伟伟(1981-) 女, 河南信阳人，景德镇陶瓷大学助教，主要从事思想政治教育研究 王否峰 (1979-), 男, 河南周口人, 博士, 景德镇陶瓷大学讲师, 主要研究方向: 马克思主义理论、生态社会主义

\section{References}

[1] The Collection of Marx and Engels (Vol. 5), Beijing: People's Publishing House, 2009: 579

[2] Engels. Dialectics of Nature. Beijing: People's Publishing House, 1984: 304-305

[3] Wang Muzhen. Study on the Development of Ecological Agriculture in China from the Perspective of Ecological Civilization. Nanchang University .2008: 29

[4] Shao Yong. Study on Comprehensive Development and Model of Ecological Agriculture in Northern Mountainous Area of Laiwu, China Ocean University, 2010: 30-31 
[5] Ye Qianji. Ecological agriculture. Sichuan: Chongqing Publishing House, 1988: 49

[6] Li Wenhua. Ecological Agriculture - Theory and Practice of Sustainable Agriculture in China. Chemical Industry Press, 2003: 20-21

[7] Zhang Xunhua, Recycling Economy: An Ideal Economic Model for Sustainable Development. Journal of the Chinese Academy of Sciences. 2004 (6): 409

[8] Li Jingjing. Performance Evaluation of Ecological Agriculture Construction in Sichuan Province. Sichuan Agricultural University, 2011: 45-46 